\title{
Which urban development for Algiers far from oil dependency? Towards TOD solutions
}

\author{
Mohammed BOUBEZARI, ULHT, Portugal.
}

\begin{abstract}
This paper is questioning which kind of urban development is adequate for Algiers far from oil dependency and basing on what was achieved since the approval of its Masterplan in December 2016 and regarding to the potentialities and opportunities already set in the territory.

The very principle of development in the territorial model already outlined a solution oriented towards the reorganization of traffic according to a principle of macro-mesh transport network structuring a new poly-centrality. At the nodes of this network, the place of these centralities, exchange hubs have been programmed. Thus, all the conditions are met so that in a second step, in terms of details, the city of Algiers can opt for a Transit-Oriented Development TOD that makes Algiers an attractive and competitive territory. By an analysis of the contents of the policy orientations of the PDAU (masterplan) of Algiers ${ }^{1}$, a participative observation of the actions carried out by the city of Algiers, one will identify the goals already achieved for the development strategy plan. One will also show that the TOD solution is the easiest if not the only one and that all the legal and strategic conditions are met to facilitate the transition to detailed development plans.
\end{abstract}

\section{Keywords}

Territory resources, TOD, Algiers Urban Development, new Centralities, Transport network.

The development strategy of the Wilaya of Algiers defined in its Master Plan was approved in December 2016. The very principle of development in the territorial model already outlined a solution oriented towards the reorganization of traffic according to a principle of structuring macro-mesh transport network a new poly-centrality. Thus, everything announces a very opportune predisposition to adopt TODs in the detailed POS plans (Land Use Plans) ${ }^{2}$.

The methodology consisted in analysing the contents of the Plan of Algiers in the sense of its suitability for a development in the detailed plans POS according to the principle of TOD.

\footnotetext{
${ }^{1}$ PDAU d'Alger (Plan Directeur d'Aménagement et d'Urbanisme d'Alger) Masterplan of Algiers.

${ }^{2}$ Le POS (Plan d'Occupation des Sols) Land Use Plan
} 


\section{What is at stake in Algiers?}

First and foremost, it is important to present the initial data on the urban planning issue of Algiers. Capital of Algeria, a country whose economy is almost totally dependent on hydrocarbons. Gas and oil represent $95 \%$ of Algeria's exports.

With the demographics still increasing on average by around 2\%, the population is estimated in 2020 at 43.9 million inhabitants ${ }^{3}$.

The population of Algiers, according to the general census of the population of 2008 was $2.98 \mathrm{M}$. inhabitants was estimated at $3.27 \mathrm{M}$. for 2019 but if the current estimations are precise, it is probable that the population of Algiers has reached $3.6 \mathrm{M}$. inhabitants today, that is to say what has been planned for 2030 !
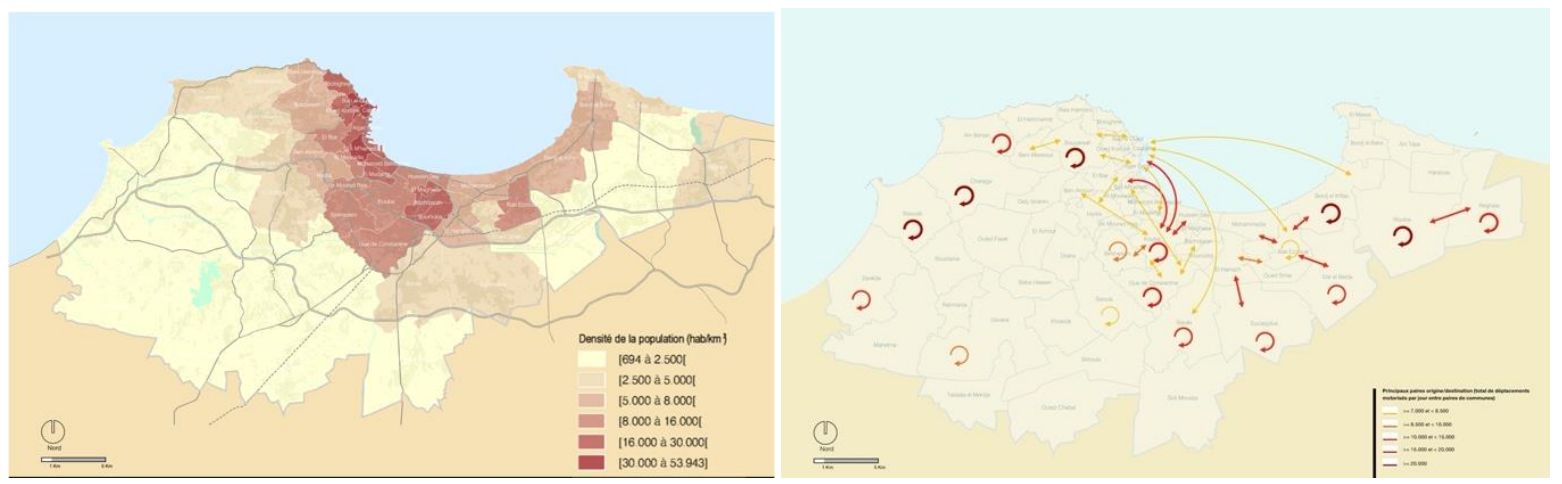

Fig 1. Population density of Algiers in 2008 (Left) inter-municipal flows (Right) (Source : TiS-Parque EXPO- Atlas d’Alger.)

For Algiers, the population is concentrated in the hyper-center (Fig.1) and movements are concentrated and focused on this same hyper-center. This creates insurmountable traffic problems, especially at peak times. If this hyper-centrality problem is not resolved, it will be aggravated as shown by the estimations for 2029 (Fig. 2)
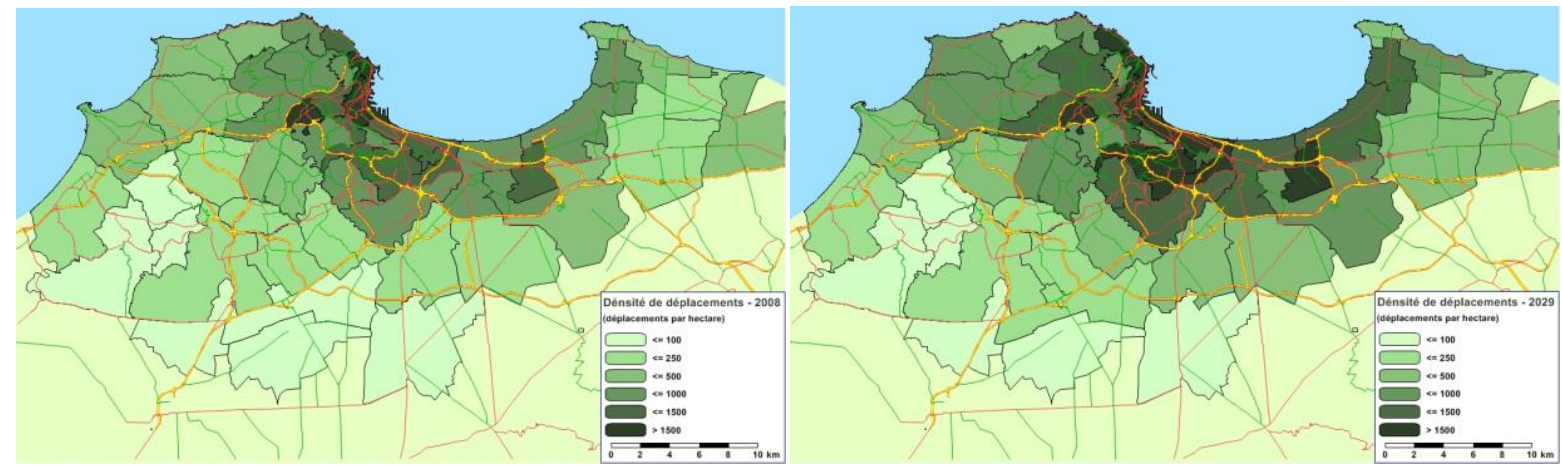

Fig 2. Densité de déplacements motorisés en 2008 et en 2029 (Source : TIS-PARque EXPO- PDAU d’Alger.)

${ }^{3}$ http://www.andi.dz/index.php/fr/statistique/demographie-algerienne-2017 
This also means that the planned population projection scenario is accelerated or exceeded. However, the Algiers plan (PDAU d'Alger) is being implemented according to another already pre-established rhythm and which is currently undergoing disruptive obstacles due to the very tense political climate. The ambitions designed for Algiers cannot ignore this even stronger demographic pressure, at the risk of jeopardizing the entire project. The main ambitions are:

- Positioning: Algiers "emblematic city"

- Socio-economic fabric: Algiers "engine of tertiary development in Algeria"

- Land occupation: Algiers "a beautiful city that controls its sprawl"

- Environment: Algiers "garden city"

- Mobility: Algiers "city of mobility and proximity"

- Risks: Algiers "safe city"

- Governance: Algiers "city of good governance"

So, what is at stake in Algiers? Based on the same type of data from 2010 but worsened with the current multidimensional crisis, the issues are:

- Control of the urban development by avoiding urban sprawl on agricultural land;

- Agricultural land is a valuable source for the economic paradigm shift;

- Create the conditions for international territorial competitiveness, which is conditioned by the establishment of conditions for welcoming investors;

- Ensure easy, diversified and efficient mobility of both goods and people;

- Rethinking the city through intelligent and efficient densification in a policy of controlled urban renewal because it is the only way out for Algiers.

Starting from these challenges and ambitions with a clear and programmed strategic vision, Algiers is taking up the challenges that arise.

\subsection{Zero declassified agricultural land}

Zero agricultural land to be decommissioned in the future means that the capital will refrain from any further sprawl beyond the urban perimeter. This makes it necessary to rethink the densification of already urbanized areas (Fig.3). But in order to avoid overloading the current hyper-center with this new issue, the logic of polycentricity around exchange poles of excellence is naturally imposed. And polycentricity requires an efficient transport and mobility network for goods and people. Consequently, a global mesh of mobility and transport based on these new centralities to be developed becomes the obvious solution.

This latest update to the Algiers PDAU is certainly the last to allow the use of 7.226 needed for this plan. Fortunately, 3.305 hectares come from not used lands of the previous plan. 3965 were taken from noncultivable land or from wasteland. Only 431 hectares are still reserved for future actualization of this plan after 2035. That means that regarding to the population growth, the urban development can only take place inside the same urbanized areas. 


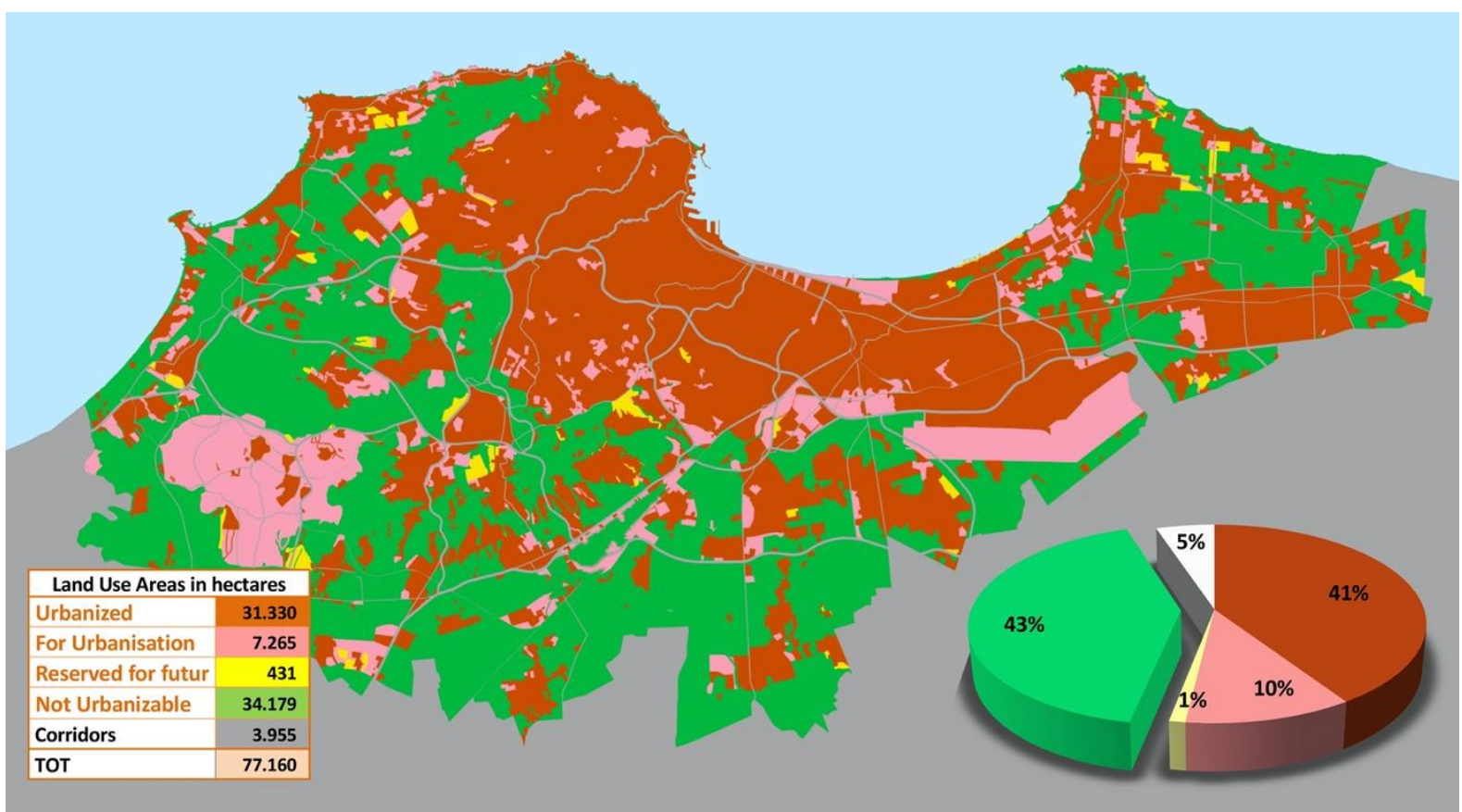

Fig. 3 GLobAL LAND USE OF ALGIERS

\subsection{Polycentricity and Mobility}

These forecasts demonstrate the urgency of modifying the mobility habits of Algiers and the importance of setting up a hierarchical and efficient public transport network, capable of controlling this growing mobility, and which requires the adoption of a corridor structure. A macro-mesh transport network was designed for Algiers from existing networks (Fig.4) and adopted (Fig.5).

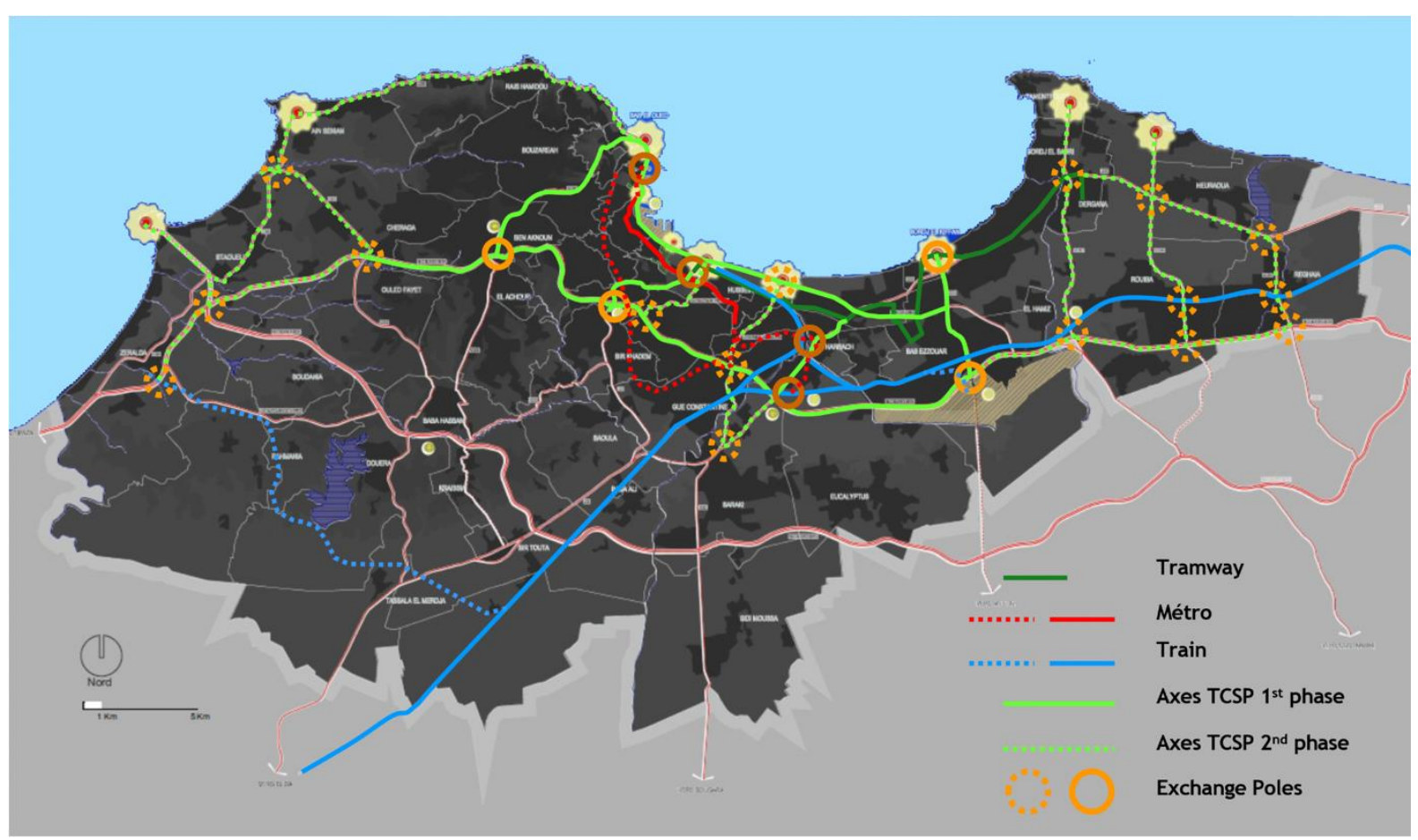

FIG. 4. SKETCH OF THE TRANSPORT AND MOBILITY SYSTEM - MACRO-MESH 
In the nodes of this macro-mesh, multimodal relay car parking and exchange poles have been planned to encourage a concentration of urbanization all around them (Fig.5).

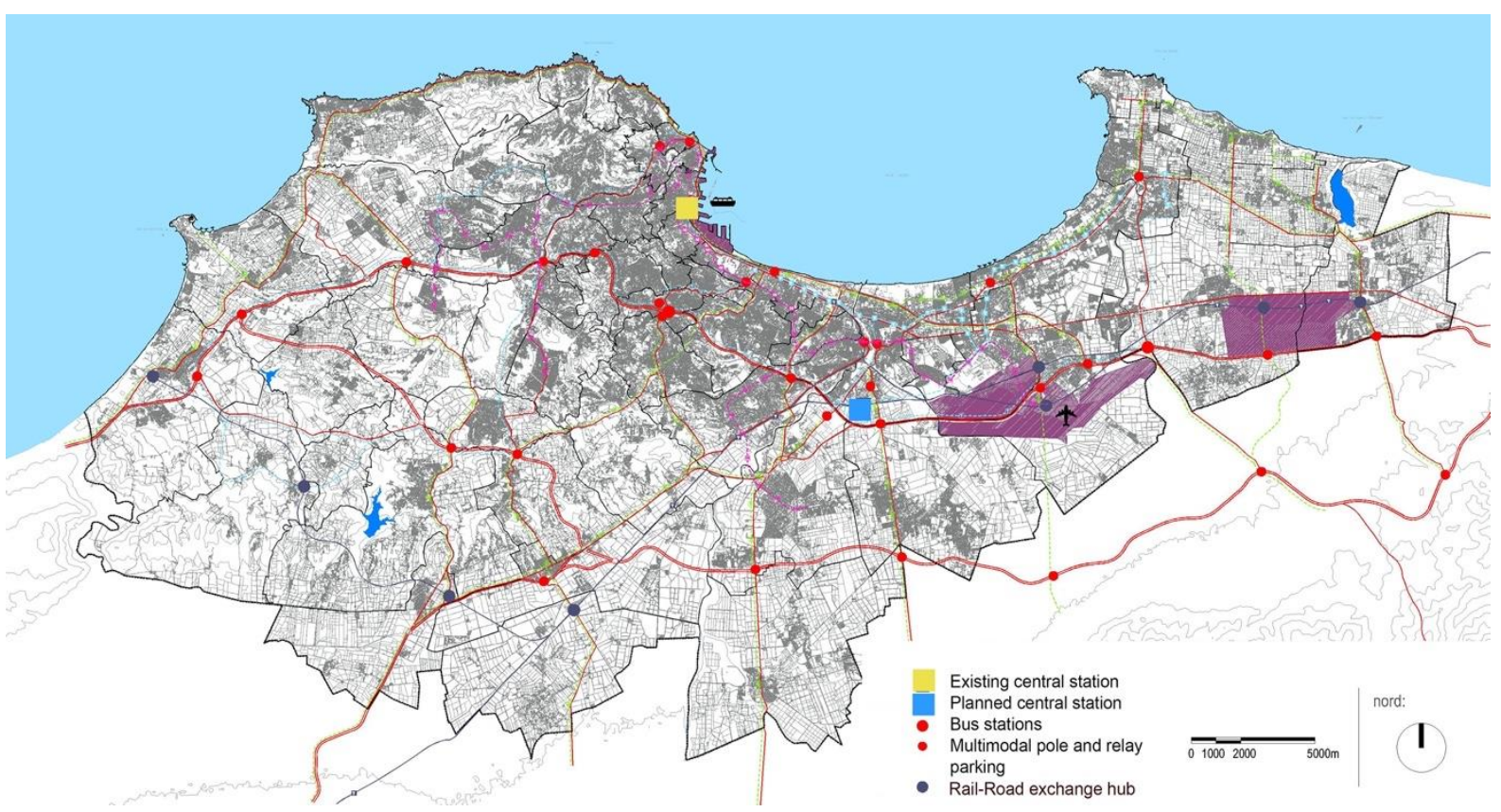

Fig. 5. Final Design of the Transport and Mobility System With EXchange Poles

These exchange poles strengthen the synergy between modes of transport. They must be fitted out in compliance, in order to maximize the potential of the transport system. Among all these hubs, some will be intermodal stations. In this specific case, it is the strengthening of the role of the railway within the transport system that is targeted, ensuring good intermodal structures that facilitate connection with other means of collective transport and individual transport.

From the concept of exchange poles, it is now more interesting to make a qualitative leap towards the concept of TOD because the regulations of the PDAU already foreshadows the possibility of TODs at the place of Poles of exchange. And it is in these areas to be densified, that Algiers will find development solutions to replace indefinite sprawl. In the following table extracted from the regulations of the PDAU of Algiers, the article 106 stipulate that:

"The possibility of bands of urban densification that apply:

- around public transport routes on their own site,

- near roads crossing peripheral urban centralities,

- near the tracks of the structuring road network (macro-mesh),

The densification only applies to the two blocs closest to either side of the structuring road network, the tramway lines, and the other lines of public transport on their own lane,

it also applies to the blocs closest to metro entrances and whose perimeter will have to be defined in a detailed POS study." 

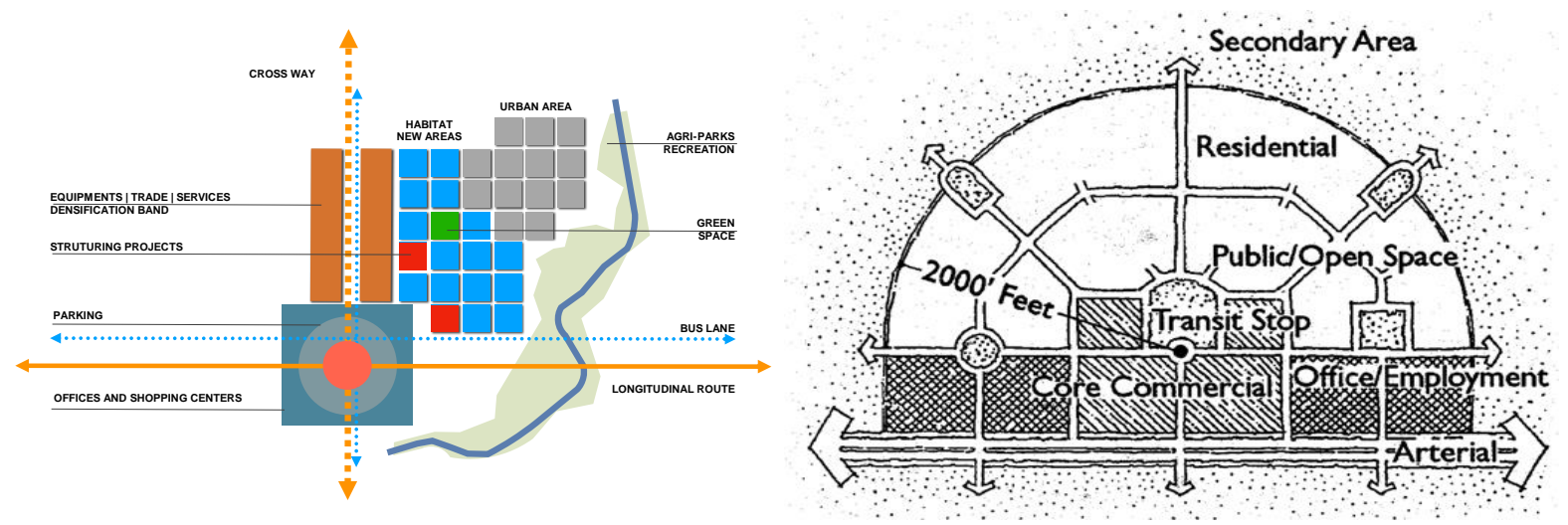

FIG. 6. NEW URBAN POLARITIES MODEL, PARQUE EXPO 2010 (LEFT) AND

THE ORIGINAL ILLUSTRATION OF THE TOD MODEL BY CALTHORPE (RIGHT)

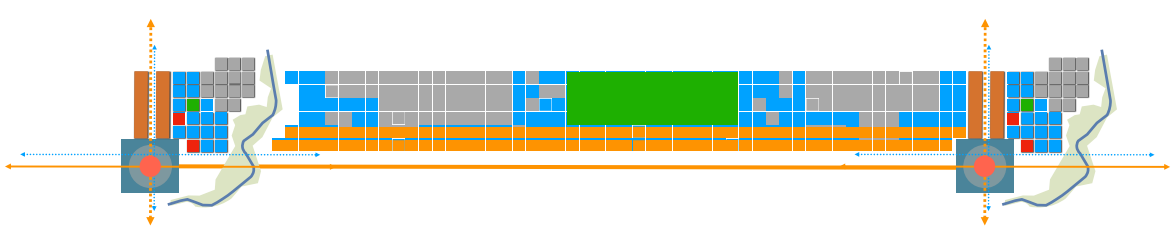

Fig. 7. DENSIFICATION BAND ALONG THE CONNECTION BETWEEN TWO TODS

In the approved documents of PDAU d'Alger, poles of exchange are defined so that to ensure:

- efficient staking of pedestrian flows, either within the interchange hub, or on routes to / from the main sources of movement located up to 450 meters;

- dissemination of important information on the offer serving the trading hub;

- the guarantee of sale of all transport tickets necessary for the use of the modes present on the exchange hub during the entire operating hours;

- adequate conditions of access to the services offered by public transport;

- good conditions of safety, lighting and cleanliness;

- access to people with reduced mobility (or a corrective adaptation plan to guarantee it in the short term);

- the existence of an integrated safety plan, to be triggered by the manager if necessary (1st and 2nd level exchange centers);

- that the management of the exchange hub be integrated and ensured by one of the operators present, by a consortium of operators present or by an entity engaged for this purpose, which will have to appoint a manager;

All these conditions contribute to the design and easy realization of future TODs around new centralities.

The details of hierarchy of the classification of future and existing exchange poles in the Wilaya of Algiers are already detailed in the documents. 


\begin{tabular}{|c|c|c|c|}
\hline CARACTÉRISTIQUES & $1^{\text {ER }}$ NIVEAU & $2^{\mathrm{E}}$ NIVEAU & $3^{\mathrm{E}}$ NIVEAU \\
\hline Function & $\begin{array}{l}\text { Main entrances to the city, either for } \\
\text { public transport or for individual } \\
\text { transport passengers whose option is } \\
\text { to park in a park and use public } \\
\text { transport to reach their destination. }\end{array}$ & $\begin{array}{l}\text { Important connection points for } \\
\text { pendular flows without the relay car } \\
\text { park component or crossing points of } \\
\text { two or more lines of the structuring } \\
\text { network. }\end{array}$ & $\begin{array}{l}\text { All the points of the public transport } \\
\text { network with a connection between the } \\
\text { lines of the network, having, at least, } \\
\text { one line of the structuring network, and } \\
\text { with a flow of corresponding } \\
\text { passengers lower than that defined for } \\
\text { the exchange poles of 2nd level. }\end{array}$ \\
\hline $\begin{array}{l}\text { Link to the structuring } \\
\text { network }\end{array}$ & Obligatory & Obligatory & Obligatory \\
\hline $\begin{array}{l}\text { Flow of connecting } \\
\text { passengers }\end{array}$ & & $>25.000$ passengers/day & $<25.000$ passengers/day \\
\hline Specific conditions & $\begin{array}{l}\text { Mandatory conditions: } \\
\text { - Guaranteed connection to the } \\
\text { structuring network; } \\
\text { - Reduction of high-demand peripheral } \\
\text { public transport (> 50,000 connecting } \\
\text { passengers / day); supply can be } \\
\text { provided by rail or road transport. } \\
\text { Desirable conditions: } \\
\text { - Location close to the nodes of the } 1 \text { st } \\
\text { level road network; } \\
\text { - Medium to high capacity for long-term } \\
\text { parking (relay parking). }\end{array}$ & $\begin{array}{l}\text { One of the two conditions is mandatory: } \\
\text { - Guaranteed connection to the } \\
\text { structuring network with a flow of }> \\
25,000 \text { connecting passengers / day; } \\
\text { - Feed-back to a line of the structuring } \\
\text { network, from public transport systems } \\
\text { with a similar demand (in } \\
\text { correspondence). }\end{array}$ & $\begin{array}{l}\text { Served by, at least, one line of the } \\
\text { structuring network. }\end{array}$ \\
\hline
\end{tabular}

Fig. 8. Classification and Exchange poles Hierarchy in the Wilaya of Algiers, (SOURCe: PDAU d’Alger)

So what kind of centrality is about?

Given the rapid increase in demographics, the solution of the exchange poles no longer seems sufficient. The need to fix populations or channel mobility in the same corridor and the encouragement of the use of public transport sends us back to a higher logic which is that of TODs. Initiated by Calthorpe in 1992 in San Diego and published in 1993, the of TOD model is based on a public transport hub. Neighbourhoods focused on a public transport hub correspond to urbanization cores located near public transport hubs.

Does Algiers fulfil the 6D conditions of TOD?

\section{The 6D conditions of TOD for land use plans (POS)}

The Algiers PDAU is an innovative instrument which has provided Algiers with modern and contemporary means for its development. The passage to the study of details must follow this logic of innovation. The detailed studies, locally called POS (Plan d'Occupation des Sols) in French, must seize all the innovative opportunities offered by the PDAU, which has the force of a law, and which converge favorably on the implementation of new centralities on the principle of TOD. the relationship between transport and urban development must be understood as a relationship of mutual dependence regarding to Claude BEAULAC (2017) "one is not the cause of the other, and vice versa. It is the interactions between transport and town planning that produce urban spaces.". In the case of Algiers, the goal is to create new centralities to unclog the center and minimize travel. These are exactly the virtues of TODs as recommended by CALTHORPE [1993] for the city of San Diego in 1992.

Another advantage that we see in the principle of TODs for Algiers is that of designing the centralities at local scales, where densification is the rule, while keeping a logic at the global scale that of the macromesh transport networks. 


\subsection{D1 Destinations: Coordinate land use and transportation}

When transport and land use are well coordinated, and this should be done by an intermediate structural plan between the PDAU and the POS. The macro-meshing of transport networks and the location of exchange poles is already done in the case of Algiers. Public transit can provide quick, direct, and costeffective access to more destinations for more people.

\subsection{D2 Distance: Create a well-connected street network}

The macro-meshing networks transport is a road network designed to be well connected to shorten travel distances, allow people to walk or cycle quickly and easily to where they want to go in the centrality of the node location of this network, or to easily connect with public transport.

\subsection{D3 Design: Create places for people}

TODs are designed within a radius of 600 to 800 meters. This value is that of feasible comfortable pedestrian movements that do not require the use of vehicles to get around. To do this, the detailed plans (POS) must design comfortable spaces and for this, the PDAU of Algiers has already adopted a public spaces guidance which guides the quality of public spaces in this direction.

\subsection{D4 Density: Concentrate and intensify activities near frequent transit}

Designing a distance of access to collective means of transport for a maximum of population brings us back to the simple logic of densification around exchange poles (Fig.6) or along the traffic corridors of the Macro-Meshing Network Transport (Fig.7) of which PDAU regulations are already made in this direction.

\subsection{D5 Diversity: Encourage a mix of uses}

The Algiers zoning plan has been designed to allow great flexibility for new centralities around or near the interchange poles thanks to multifunctional zones. They are designed to facilitate a mix of uses in future retail plans (POS).

\subsection{D6 Demand Management: Discourage unnecessary driving}

There is still a need to monitor and encourage residents to minimize the use of cars by using the parking zones designed for this purpose and to use the collective transport. There are many incentive measures, but they need to be led and continuously monitored by an institution dedicated to this function. The PDAU has provided that the Society for the Development of Algiers can fulfill this role.

\section{Algiers 2035 and the structuring projects of the Algiers strategic plan}

Algiers has a strategic plan that extends up to 2035, based on achievable ambitions and clear and defined objectives on different scales and at different stages. The paradigm of the economic development linked to the strategic plan changes completely. It considers the territory as a resource and not as a charge financed by the rent from hydrocarbons. The strategic plan definitively stops the urbanization of agricultural land and the ecological structure to rebuild the city on the city.

The cultural heritage which is the driving force for tourism development is also considered a resource and this resource is infinite. The inhabitants of the city, are also a resource, always renewed, they are the ones who make Algiers a smart city of reference by their intelligent uses of the urban space. 
The development strategy of Algiers spanning 4 stages for twenty years, was first approved in the form of a Strategic Action Plan from 2009 to 2029 and endowed with an autonomous budget, had to undergo a switch at the moment of the approval of the Master Plan (PDAU d'Alger), from 2015 to 2035. Designed to be operational, it consists in concrete terms in the realization in programmed stages and by a governance which ensures the coherence of the whole plan, of 82 projects structuring the territory and major events structuring the calendar of these achievements.

Thanks to this 6-year switch, Algiers ended up with $29 \%$ of goals achieved (Fig.9). They are distributed over the 4 stages in advance. The delay is due to the fact that $45 \%$ of the Strategic Plan is concentrated on the first 5 years. This delay can be made up.

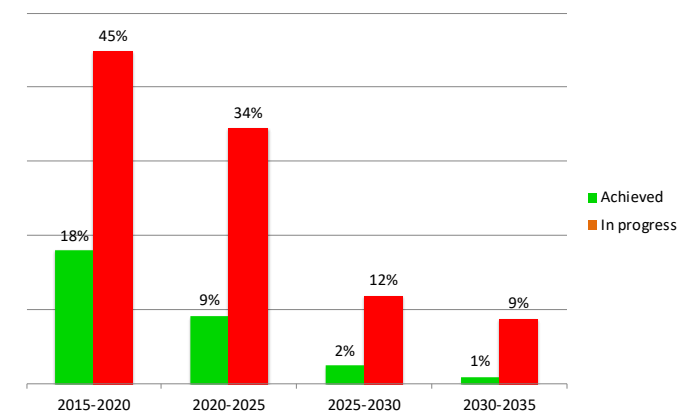

Fig. 9. Progress of the structuring projects of the Algiers strategic plan

But what is the relationship with Transit Oriented Development?

These Structuring Projects are only effectively structuring if they participate in this development dynamic around the nodes of the macro-mesh network of transport where exchange poles are located often close to old historical heritage centralities. One example is the Great Mosque of Algiers, Djamaa el Djazaïr. The prayer hall has a capacity of 37,000 worshipers, while the structure including the compound can house up to 120,000 worshipers and has parking space for 7,000 cars.

An exchange pole with various collective transports is urgently needed for this area.
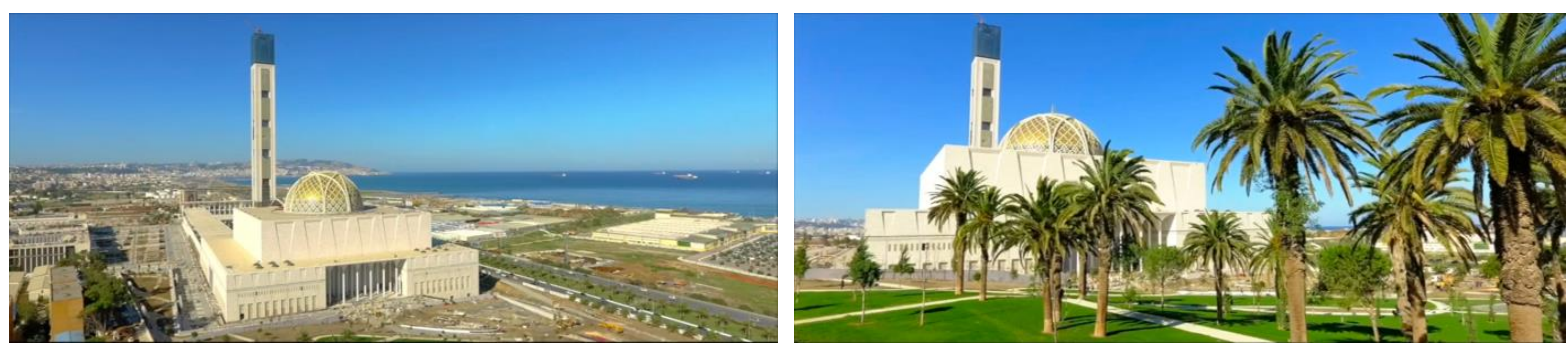

Fig. 10. Strong Potential TOD ARound the DJAmaA El DJaZAïr 


\section{Conclusion}

More than a planning instrument, the PDAU of Algiers was designed as an urban project for the twenty years (2015-1035). Far from any functionalist conception which has shown its limits, the Algiers PDAU demonstrates a great concern for operationality. Thus, instead of imposing itself as an ideal pattern on the territory, it starts from the concrete located structuring project that encourage locally the economic and urban development. The one-off project itself creates a new centrality which, along with other centralities logically distributed across its extent, create flows that bind and structure the territory through what has been defined as the macro-mesh transport network. This is how the so-called structuring projects form the framework on which the capital will be built.

The structuring projects were defined with rigor, in consultation with the actors of the city and in accordance with the sectoral policies whose representatives were consulted. The capital's strategic development plan, which was approved by the Inter-ministerial Council of November 14, 2011, commits each of the city's sectoral policies for the realization of these structuring projects. The operationality of the PDAU is therefore a reality already in motion.

The green zones made up of an ecological structure and a fundamental agricultural reserve are permanently sealed in this new version of the PDAU, thus forcing the development of the city to take place in its own urbanization zone, by densification, rehabilitation, conversion etc. The downgrading of agricultural land to meet the urgency of the demand is definitely ruled out.

But given that the demographics are larger than expected, given the political tension triggered by the demands of the Hirak movement, it is time to move on to the detailed plans and opt for the TOD solution with a strong participation of population in the projects of the new centralities of the new TODs. To do this, the Wilaya of Algiers must call on TOD experts for specialized engineering studies. The financing of the remaining structuring projects and the development of the TODs must also be managed by the Algiers Development Company stipulated in the plan. It must be a joint stock company and the main shareholder will be the Treasury. The projects must be financed by bank loans supported by more complex financial arrangements in order to definitively stop consuming hydrocarbon resources instead of investing them in development. Technically, Algiers already fulfils all the conditions for a transition to TODs. This is what we have tried to demonstrate by analysing the content of the Plan, the study of which we ourselves conducted from 2012 until its approval in 2016. The success depends on engineering of the TOD and the consultation and confidence which can be established with the population at the end of the current political crisis.

\section{References}

Algerian National Agency of Investment Development Official website (2017) Available at: http://www.andi.dz/index.php/fr/statistique/demographie-algerienne-2017,(accessed $\quad 15$ octobre 2020)

Amoroso, S., Castelluccio, F. and Santoro, N. (2012) 'Sustainable mobility: "exchange poles" between transport networks and urban structure', The Sustainable City, VII, Vol. 2, WIT Press, pp 955-966.

Bartholomew, K., Ewing, R. (2011) 'Hedonic Price Effects of Pedestrian and Transit-Oriented Development', Journal of Planning Literature, 26 (1), pp.18-34.

Boucher, I. and Fontaine, N. (2011) L'aménagement et l'écomobilité, Guide de bonnes pratiques sur la planification territoriale et le développement durable. Ministère des Affaires municipales, des Régions et de l'Occupation du territoire, $232 \mathrm{p}$. 
Calthorpe, P. (1993) The Next American Metropolis - Ecology, Community and the American Dream. Princeton Architectural Press: Canada.

Cervero, R. and Arrington, G.B. (2008) Effects of TOD on Housing, Parking, and Travel, Rapport produit dans le cadre du Transit Cooperative Research Program (TCRP 128), Washington : Transportation Research Board, $67 \mathrm{p}$.

Cervero, R. and Sullivan, C. (2011) 'Green TODs: marrying transit-oriented development and green urbanism', International Journal of Sustainable Development \& World Ecology, 18(3), pp.210-218.

Cervero, R., Ferrell, C. and Murphy, S. (2002) Transit-Oriented Development and Joint Development in the United States: A Literature Review, Rapport produit dans le cadre du Transit Cooperative Research Program (TCRP 52), Washington : Transportation Research Board, 144 p.

Communauté Métropolitaine De Montréal [CMM] (2012). Guide d'aménagement pour les aires de TOD (Transit Oriented Development), 84 p.

Ogra, A., Ndebele, R. (2014) 'The role of 6Ds: Density, diversity, design, destination, distance, and demand management in transit oriented development (TOD)', Proceedings of the NeoInternational Conference on Habitable Environments (NICHE 2014), CreateSpace Independent Publishing Platform (11 October 2014), Jalandhar, India, 31 October-2 November 2014.

PDAU d'Alger, Plan Directeur d'Aménagement et d'Urbanisme d'Alger, Parque EXPO, Wilaya d'Alger, 2016.

ATLAS d'Alger, Parque EXPO, Wilaya d'Alger, 2010.

Renne, J.L. (2005) Transit-Oriented Development: Measuring Benefits, Analyzing Trends, and Evaluating Policy. New Brunswick (NJ) : The State University of New Jersey, 240 p.

Renne, J.L. (2009) 'From Transit-Adjacent to Transit-Oriented Development', Local Environment, 14 (1), pp. 1-15.

Sung, H. and Oh, J. (2011) 'Transit-oriented development in a high-density city: Identifying its association with transit ridership', Cities, 28(1), Seoul, Korea, pp.70-82.

TRANSLINK (2012) Transit-oriented Communities Design Guidelines. Creating more livable places around transit in Metro Vancouver. Burnaby (B.C.) : TransLink, 172 p.

VIVRE EN VILLE (2014) Retisser la ville : [Ré]articuler urbanisation, densification et transport en commun, 2nd edn. 108 p. 